\title{
Thomas Hobbes'un İnsan Felsefesi Bağlamında The Platform (2019) Filmi Üzerine Bir Analiz
}

\author{
An Analysis on The film The Platform (2019) in The Context of Thomas \\ Hobbes' Human Philosophy
}

\author{
Eşref Akmeşe \\ Arş. Gör. Dr., İnönü Üniversitesi, İletişim Fakültesi, Radyo Televizyon ve Sinema Bölümü \\ email: esrefakmese@gmail.com (DORCID ID: https://orcid.org/0000-0003-0906-8928
}

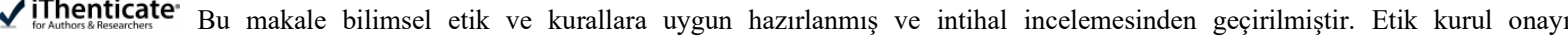
gerektirmemektedir.
\end{abstract}

Atıf (APA 6)/To cite this article

Akmeşe, E. (2021). Thomas Hobbes'un insan felsefesi bağlamında The Platform (2019) filmi üzerine bir analiz. Atatürk Üniversitesi Güzel Sanatlar Enstitüsü Dergisi, 27(46), 221-230. https://doi.org/10.35247/ataunigsed.833122

Makale Gönderim Tarihi/Received: 29/11/2020

Makale Kabul Tarihi/Accepted: $18 / 01 / 2021$

Makale Yayun Tarihi/Published: 30/03/202

Review Article/Derleme Makale

Öz

Antik Yunan felsefesinde insanın ne olduğuna dair düşünceler, genellikle "kendini bil" sözüyle başlatılır. Günümüzde insan doğasına ilișkin felsefi tartıșmalar açısından "kendini bil" sözü önemini korumaktadır. $\mathrm{Bu}$ söz etrafında geliştirilen felsefi tartışmalar genellikle insanın özü ya da insanın doğası üzerinden yapılmaktadır. Bu bağlamda "insan doğası" kavramı, insanın ne olduğu ve ne olabileceği yönündeki tartışmaların temel dayanağını olușturmaktadır. İnsan hakkında yapılan felsefi tartışmalar, temel malzemesi insan ve insan yaşamı olan sinema filmlerine de yansımaktadır. Bu bağlamda İspanyol yönetmen Galder Gaztelu - Urrutia imzalı The Platform (2019), insanın ne olduğuna ve ne olabileceğine dair düşünceler etrafında kötümser insan imajları içeren tasvirleriyle felsefi potansiyeli belirgin bir film olarak dikkat çekmektedir. Bu çalışmada insan doğasının niteliğine dair önemli bir felsefi argüman olan "insan insanın kurdudur" sözünü sinematik olanaklarla somutlaştıran The Platform, insan doğasına yönelik söylem üzerinden ele alınmakta ve İngiliz filozof Thomas Hobbes'un "doğa durumu" ve "toplumsal sözleşme" kavramları bağlamında içerik çözümleme tekniği kullanılarak nitel analizle irdelenmektedir.

Anahtar kelimeler: İnsan Doğası, Doğa Durumu, Toplumsal Sözleşme, Platform (Film), Thomas Hobbes

\begin{abstract}
In Ancient Greek philosophy, thinking about humans was started with the sentence "know yourself" in general. This motto maintains its importance for human philosophy concerning philosophical debates on human nature. Philosophical debates centered around this sentence are generally around human essence or nature. In this context, the concept of "human nature" constitutes the basic foundation of discussions about what human is and what human can be. Philosophical debates about human beings are also reflected in films, the basic material of which is human and human life. In this context, The Platform (2019), by Spanish director Galder Gaztelu - Urrutia, draws attention as a film with a distinct philosophical potential with its romantic and pessimistic portrayals of human images around the thoughts about what human beings are and what they can be. In this study, The Platform, which embodies the phrase "man is a wolf to man", which is an important philosophical argument about the characteristics of human nature, with cinematic possibilities, is addressed through the discourse on human nature and is examined by qualitative analysis within the scope of concepts "state of nature" and "social contract" of British philosopher Thomas Hobbes.
\end{abstract}

Keywords: Human Nature, State of Nature, Social Contract, The Paltform (Film), Thomas Hobbes

\section{Giriş}

İnsanı insan yapan özellikleri ifade etmek için başvurulan insan doğası hakkındaki düşünceleri farklı perspektiflerden ele alan birçok teori söz konusudur. İnsan doğası üzerine ileri sürülen düşünceler farklı insan modellerinden yola çıkarak yaşamın örgütlenmesi ve anlamlandırılması için çeşitli perspektifler sunarlar. İnsan doğası belirli özelliklere indirgendikten sonra, insan hakkında görüş bildirmek ve toplumsal yaşamın nasıl örgütlenmesi gerektiği hakkında hüküm vermek daha basit olmaktadır. Bu doğrultuda insan doğası kavramı, insana yönelik genellemelerin yapılması ve insanın belli özelliklere indirgenerek tanımlanması için pratik bir işlev görmektedir. İnsan doğası kavramıyla, insanın toplumsal bir varlık oluşu, içinde yaşanılan çevrenin etkisi ve yaşam deneyimleri ikinci plana itilerek insanın doğal olarak sahip olduğu nitelikler ön plana çıkarılır. Bu doğrultuda insan hakkında bir hüküm verildikten sonra insanın ne olduğu ve ne olamayacağı da belirlenir. İnsan doğası gereği bencildir ya da insan doğası gereği kötüdür benzeri düşünceler kabul edildikten sonra insanlara güvenmek ya da insanların dayanışmalarını beklemek anlamsızlaşır.

İnsanın özü ya da insanın doğası kavramlarının kullanılması insanın karmaşık özelliklerini göz ardı etmez ancak insanın ne olduğuna dair temel düşünceyi açıklar. Bu doğrultuda insan eğer bir öze sahipse ve bu onun doğal yapısının gereğiyse insanın bu öze uygun biçimde davranması, yaşaması gereklidir sonucu ortaya çıkar. Bu bağlamda insan doğası, bilimsel açıdan oldukça tartışmalı bir kavram olsa da insan üzerine yapılan değerlendirmeler açısından işlevsel bir kullanıma sahiptir. $\mathrm{Bu}$ durum insana atfedilen niteliklerin değişmeyeceğini ve insanın doğal yapısına içkin olan özelliklerin değiştirilemeyeceğini imler. İnsanın doğası 
biyolojik, fizyolojik ve psikolojik faktörlerle açıklansa da asıl amaç bu kavramla insanın sosyal bir varlık olarak ne olduğu ve hangi koşullarda yaşaması gerektiği yönündedir. İnsanların doğaları gereği kötü oldukları düşüncesi genellikle, kurt metaforu kullanılarak "homo homini lupus", yani “insan insanın kurdudur" sözüyle desteklenmektedir. Thomas Hobbes (1588 -1679), tarafindan Elementa Philosophica De Cive (1642), adlı eserde kullanılmasından sonra popülerleşen "homo homini lupus" sözü günümüzde insan ve politika felsefesi alanında etkili bir motto olmayı sürdürmektedir.

\subsection{Thomas Hobbes'un İnsan Felsefesi}

\subsubsection{Insan Doğası}

Düşünce tarihine bakıldığında, insanın ne olduğu ve nasıl yaşaması gerektiği gibi tartışmaların insan doğası kavramıyla temellendirildiği görülmektedir. İnsan doğası, felsefe alanında insanın kendi üzerine düşünmesi için temel odaklanma merkezini oluşturur. Cassirer (1980, s. 13), İnsan Üzerine Bir Deneme adlı çalışmasında bu durumu, "Felsefe araştırmalarının en yüksek ereğinin kendini-bilme olduğunu genellikle herkes onaylar. Bu erek, ayrı felsefe okulları arasındaki bütün çatışmalarda değişmez ve sarsılmaz erek olarak kalmış, bütün düşüncenin kalkış noktası, belirli ve değişmeyen merkezi olduğunu kanıtlamıştır” şeklinde açıklar. Bu eksende ileri sürülen görüşler, modern düşüncenin merkezi sorunları arasında yer alarak tartışılmaya devam etmektedir. Modern birçok sosyal bilimci, "insan doğası" kavramı karşısında konumlanır, onlara göre, insan doğası diye bir şey yoktur ve insan boş beyaz bir kâğıt gibi doğup dünyaya geldikten sonra kültür tarafından biçimlendirilir. Bu görüşün karşısında ise insanın değişmeyen bir öze sahip olan kavranabilir nitelikte bir varlık olduğunu savunan düşünürler bulunmaktadır (Fromm, 2014, s. 47). Bu doğrultuda insanın doğal olarak bir öze sahip olup olmadığ ya da insanın herhangi bir öze sahip olmayıp sonradan çevre ve eğitim gibi faktörlerin etkisiyle şekillendirilebileceği yönlü tartışmalar farklı perspektiflerden yapılmaktadır.

Tüm insanların asli ve değişmez özelliklerini ifade etmek için kullanılan insan doğası kavramı, pratik anlamda insanların gerçekte ne olduklarına yönelik basitleştirilmiş genellemelere başvurmak için işlevsel bir kullanım imkânı sunar. $\mathrm{Bu}$ açıdan pratikte insan doğasından söz edildiğinde hem insanlar hakkında hem de insanların içinde yaşadıkları toplum hakkında önemli varsayımlar ileri sürülür (Heywood, 2004, s. 15). İnsan doğal yapısı temelinde belirli özelliklerle tanımlandığında bu durum kaçınılmaz biçimde birey ve toplum arasındaki ilişkileri açıklamak ya da düzenlemek için de kullanılır. İnsanın doğasının geçerli bir ölçüt olarak kabul edilmesi, insanın eğitim ya da çevrenin etkisiyle değişebileceği yönündeki argümanlara set çekmeyi akla getirir. Bu açıdan "insan doğası" düşüncesine dayalı çıkarımlar birey toplum ilişkilerinin yönünü de belirler. Bu eksende insan doğasına yönelik saptamalar insanların nasıl yaşamaları gerektiği dahası nasıl yönetilmeleri gerektiği gibi teorilerin oluşturulmasında önemli bir dayanak oluşturur. Bu bağlamda İnsan'ın kötücül niteliğine vurgu yapan "insan insanın kurdudur" sözüyle insanların egoist, yıkıcı ve dayanışma yerine rekabeti tercih eden varlıklar olduğu ileri sürülür. İnsan doğası kurt metaforuyla açıklandığında karamsar, kötücül bir perspektifle insanlığa yaklaşılır ve bu doğrultuda insan ve toplum yaşamının düzenlenmesi gerektiğine vurgu yapılır.

İnsanlığın geleceğine dair birbirinden farklılaşan çeşitli görüşler bulunmaktadır. Bu görüşler genellikle belirli toplumsal örgütlenme modellerini öneren nitelikler taşımaktadır. Thomas Hobbes'un belirli bir toplumsal örgütlenme modelini rasyonel temellerde savunmak için geliştirdiği doğa durumu distopik nitelikte bir kurgudur. Hobbes'un kurgusunda, herkesin herkesle savaştı̆̆ 1 koşullardaki insan hayatı, yaşanmaya değmeyecek nitelikte olumsuzluklarla örülüdür (Davies, 2010, s. 139). Thomas Hobbes, insanın karmaşık yapısının bilincinde olarak duygusal arzu nesnelerinin veya tutkuların kişiden kişiye değiştiğinin farkındadır. Bu nedenle insanın psikolojik yapısıyla ilgili ileri sürdüğü öncüllerin ahlak ve politika felsefesinde işlevsel olmaları için her insanda aynı oranda geçerli olmasını zorunlu görmez (Gert, 2006, s.164). Thomas Hobbes'un felsefesinde insan doğası üzerine geliştirilen öğreti, düşünürün çeşitli gözlemler ve soyutlamalarla çerçevesini çizdiği bir model niteliğindedir. Hobbes'un geliştirdiği insan doğası modeli, insan ve insanın davranışlarının tüm özelliklerini içermez, filozofun insan modeli insanı temsil edecek kadar etkeni içerir. Hobbes geliştirdiği insan modelinde soyutlamalara başvurur ve insanı tüm sosyal ilişkilerden soyutlayarak birey olarak ele alır. Hobbes, insanın bütün olumlu ve olumsuz yönlerini hesaba katarak soyutlama yoluyla ortaya çıkardığı insanın psiko - sosyal yapısından hareket ederek devletin gerekli olduğunu göstermeyi amaçlar (Zarakolu, 2013, s. 129-130). Bu doğrultuda Hobbes devletin varoluşunu ve egemenliğin tek elde toplanmasını, insanın çıkarları gereği olduğu düşüncesini temellendirir.

\subsubsection{Doğa Durumu}

Doğa durumu, Hobbes'un insanın doğasının ne olduğuna ve bu doğanın gereği olarak insanların nasıl davrandıklarına yönelik bir kavramsallaştırmadır. "Doğal durum, tarihsel bir durum olmaktan çok varsayımsal bir durumdur veya bir çalışma hipotezidir" (Zelyüt, 2010, s. 31). Hobbes, insanların yasalar olmaksızın yaşadıkları bir çeşit doğal durum tasarımından hareket eder. Kurgusal bir fikir olan doğal durum, insanların korkutulması temelinde toplumsal bir sözleşmeye ikna edilmeleri hedefini içerir (Svendsen, 2017, s. 139). Hobbes, insanın özünde nasıl bir varlık olduğunu açıklamak amacıyla imgelem düzleminde insanı toplumsal 
hayattan soyutlayarak "doğal halinde” ele alır. Hobbes, geliştirdiği kurgusal paradigmayla insan doğasını her çeşit toplumsal ve politik belirlenimin dışındaymış gibi betimler ve bu doğrultuda toplumsal yaşamın insan üzerindeki etki ve sonuçlarını değerlendirir (Leboeuf, 2014, s. 84). Hobbes'a (2007a, s. 94) göre, doğa durumu, herkesin herkese karşı kesintisiz biçimde savaş halinde olduğu bir durumu ifade eder: "Devlet olmadıkça, herkes herkese karşı daima savaş halindedir. Buradan şu açıkça görülür ki, insanlar hepsini birden korku altında tutacak genel bir güç olmadan yaşadıkları vakit, savaş denilen o durumun içindedirler ve bu savaş herkesin herkese karşı savaşıdır". Böylesine kaotik bir atmosfer içinde hiçbir insani üretim için sağlıklı koşulların olamayacağını ve yaşamın sürekli biçimde ölüm korkusunun gölgesinde kalacağını vurgulayan Hobbes (2007a, s. 95), doğa durumu söz konusu olduğunda "insan yaşamı yalnız, yoksul, kötü, vahşi ve kısa sürer", çıkarsamasında bulunur. Bu anlamda "doğa durumu" insan için yaşamın pek değersiz ve anlamsız olduğu bir çeşit kaotik barbarlık ortamı olarak tanımlanabilir.

Thomas Hobbes, rasyonel düşüncelere önem verir ancak ona göre, insan aklının gücü sadece amaca götüren araç olmasından kaynaklanır. Bu açıdan insanlar rasyonel olmayan nefret, korku, umut, arzu ve en etkilisi diğer insanlar üzerinde güç kullanma isteği gibi akılcı olmayan arzularla yönlendirilebilmektedir. Hobbes, insan doğasına karamsar bakışı içeren yaklaşımın etkisiyle toplumu sadece güçlü ve otokratik bir yönetimin kaos ve düzensizliğe düşmekten kurtaracağı sonucuna ulaşır (Heywood, 2004, s. 22-23). Bu temelde Hobbes, insanın akli yollardan ulaşacağı sözleşmeye dayalı bir toplumsal düzeni önererek toplumsal sözleşmeyi kaotik ortamın egemen olduğu doğal durum karşısında yegâne seçenek olarak sunar. Bu çerçevede, "Toplum sözleşmesi anlayışı, ahlaki normları toplumsal uzlaşmaya dayandırır. Ortak bir irade oluşturma süreci içinde, herkesi bağlayıcı ilkeler ve eylem kuralları tespit edilip sözleşmeyle belirlenir" (Pieper, 2012, s. 230). Bu anlamda Hobbes, akıl yoluyla insanların ortak çıkarlar zemininde bir araya gelebileceğini vurgular.

Hobbes insanların birbirlerine karşı besledikleri evrensel güvensizlik ilkesinden söz eder fakat karşılıklı korku ve güvensizlik duygusunun nedeni olarak insanların doğaları gereği kötü oldukları sonucunu çıkarmaz. İnsanı harekete geçiren unsurun iyilik istenci değil, güç ve mutluluk arayışı olduğu düşüncesinden hareket eden Hobbes'a göre, mutlak bir otoritenin bulunmadığ1 koşullarda eşit insanların güç ve mutluluk arayış1 içine girmeleri ve birbirlerine karşı savaşmaları kaçınılmazdır (Neiman, 2016, s. 42). Hobbes’a (2007b, s. 12) göre, "iyi ile kötüyü birbirinden ayıramayacağımızdan, iyilerden daha az sayıda kötü insan olsa bile, dürüst ve iyi insanlar mümkün olan her yolla kendilerini korumak için diğerlerini izleme, onlara güvenmeme, tedbirli olma ve diğerlerinden daha güçlü olma ihtiyacı içindedirler”. Bu açıdan insanların birbirlerinden korkması ve birbirlerine güvenmemeleri sürekli biçimde kaygıların canlı tutulmasına yol açmaktadır.

Hobbes'un ileri sürdüğü ana sava göre, insanların şiddete eğilimleri de insanların egemenin iktidarına boyun eğmeleri de insan aklıyla açıklanabilecek nitelikteki rasyonel kararların sonucudur. Buradaki rasyonel kararların alınmasında ise öldürülme korkusu belirleyici rol oynamaktadır (Kaufmann, 2003, s. 47). Bu doğrultuda doğal durumun olumsuzluğunu mutlaklaştıran Hobbes, insanların yasalarla ve güçlü bir otoritenin yönetimi altında yaşayabilecekleri bir sözleşme önerisiyle çıkar. Bu temelde kaotik eşitlik durumuna son vermeyi hedefleyen Hobbes, Leviathan metaforuyla açıkladığı mutlakiyetçi, otoriter ve mülkiyet haklarının korunduğu bir sistemi savunur. Leviathan, kökenleri Babil mitolojisine dayanan İbranice bir sözcüktür. Hobbes, Leviathan sözcüğünü Eski Ahit'ten ödünç alarak kullanır. Hobbes'un egemen devletin simgesi olarak kullandığı Leviathan sözcüğü, "bir görünüşüyle insanları yıkan" ve "gurur oğulları üzerinde kral olan" büyük bir su canavarını anlatmaktadır (Zabc1, 2015, s. 429).

\subsubsection{Thomas Hobbes ve Kurt Metaforu}

Hobbes'un insan anlayışıyla özdeşleştirilen “insan insanın kurdudur” sözündeki kurt ve insan karşılaştırmasına dair sava göre, insanlar düşünebilme kabiliyetleri, gelecek korkuları ve egemenlik için mücadele etmeleri gibi insani özellikleriyle hayvanlardan daha tehlikelidir. İnsan elindekilerle yetinmeyerek yeni kaynaklar ve ganimetler için sonu gelmez çabalar içine girerken yırtıcı hayvanlar karınlarını doyurduktan sonra zamanlarını genellikle uyuyarak geçirirler. Bu nedenlerle insanlar arasında sahip olduklarından memnun olanlar bile diğer insanlardan gelebilecek tehlikelere karşı savaşmak dışında bir seçenek bulamazlar (Kaufmann, 2003, s. 45). Belirgin biçimde insana kötümser bir perspektifle bakan ve insanın kötücül doğasına vurgu yapan "insan insanın kurdudur" düşüncesi genellikle insanın negatif doğasına vurgu yapmak için kullanılmaktadır. "Homo homini lupus" ifadesi Hobbes'un, De Cive adlı eserinin ithaf kısmında geçmektedir. Bahsi geçen ifade, "Her ikisi de doğru olan iki söz vardır. İnsan insanın Tanrı'sıdır ve İnsan insanın kurdudur" (Hobbes, 2007b, s. 1), şeklinde yazılmıştır. İnsanın sadece iyi ya da sadece kötü olmadığını ileri süren Hobbes, "insan insanın Tanrı'sıdır”, sözünün yurttaşların, "insan insanın kurdudur”, sözünün ise devletlerin arasındaki ilişkiler için doğru olduğunu belirtir. Hobbes'a göre; “Barışın ilkeleri olan adalet ve yardımlaşma bakımından yurttaşlar Tanrı’ya benzerlik gösterir. Ama devletlerin arasındaki ilişkilerde, kötü insanların şeytanlıkları, iyi insanları da, kendi korunmaları adına, vahşi ve düzenbaz olmaya, eş deyişle yabani hayvanların avcı ruhuna sahip olmaya, zorlar" (Hobbes, 2007b, s. 2). Bu sözlerden anlaşllacağı üzere Hobbes, "homo homini lupus" ifadesini, "doğa durumu”ndan çıkan insanların sözleşmeyle tabi olacakları devlet sisteminde, içine girecekleri ilişkileri açıklamak bağlamında 
kullanmaktadır. $\mathrm{Bu}$ açıdan "homo homini lupus" ifadesi ya da insanın diğer insanlar için kurt olarak tanımlanması doğa durumuna özgü değildir. Bu bağlamda sözleşmeyle doğa durumundan çıkışları insanlar için yeni ve daha düzenli bir aşamayı ifade etse de insanın kurt metaforuyla açıklanan doğası değişmemektedir.

Hobbes'un insan paradigması, egoist, benlikçi insanların doğal durumda, arzuları gereği birbirleriyle çatışacakları önermesine dayanır. Hobbes, toplumsal sözleşme teorisini "herkesin herkese karşı" olduğu savaş durumunu, güven, istikrar ve insanların arzularının dizginlenmesinin sağlanması adına, güçlü bir devlet önermesiyle çözmeye yönelir. Hobbes’un insan ve toplum anlayışı güçlü devlet mekanizmasının varlığını ve insanlar üzerinde mutlak bir gücün otoritesini zorunlu kılar (Newman, 2006, s. 78). Azami düzeyde istikrar ve güvenliği hedefleyen Hobbes, rekabetçi, bencil ve sürekli diğerlerinin aleyhine kendi çıkarları peşinde koşan negatif bir insan manzarası çizer. Hobbes doğal durumun söz konusu olmadığı sözleşme aşamasında bile insanların birbirleri için korku ve kaygı kaynağı olduklarını vurgular. Hobbes (2007a, s. 95) bu durumun doğal durumdan farkını "savaş duruşu” kavramıyla açıklar:

Rastgele insanların bir diğerine karşı savaş durumunda bulundukları bir dönem hiç olmamasına rağmen; bütün dönemlerde, krallar ve hükümranlık sahibi kişiler, bağımsız oluşları nedeniyle, sürekli kıskançlık içinde olup birbirlerine silahlarını doğrultmuş ve gözlerini dikmiş gladyatörler gibidirler; yani, krallıklarının sınırlarına kalelerini, ordularını ve toplarını dikmişler ve komşularına sürekli casuslar göndermişlerdir; bu bir savaş duruşudur.

Bu bağlamda doğa durumunda herkesin herkese karşı savaş durumu, sözleşme durumunda yeni bir aşamaya geçer ve devletlerin devletlere karşı savaş duruşu söz konusu edilir. Bu yeni aşamada toplumsallaşan ve uzlaşmalara dayalı örgütlenmelerle iradelerini devlet kurumuna teslim eden insanların doğası değişmez ancak yaşam koşulları değişir. Bu doğrultuda daha rasyonel, güvenli ve öngörülebilir bir yaşam ortamı söz konusu olur.

Hobbes'un çizdiği insan manzarası temel olarak siyasi yapıyla ilgilidir ve Leviathan'ın ihtiyaçlarına göre insanın özellikleri tarif edilir. Bu açıdan Hobbes insanı güce susamış bir hayvan olarak betimler ve bu duruma uygun bir siyasi düzen tasarlar (Arendt, 2014, s. 39). Hobbes'un toplumsal sözleşme teorisinde bireyler arasında ortak hiçbir bağ söz konusu değildir, insanlar kaynaklara el koymak adına sürekli birbirlerine karşı mücadele içinde bulunurlar. Bu anlamda doğal halinde toplum köklü biçimde altüst oluşla nitelenir çünkü sürekli bir savaş durumu söz konusudur (Newman, 2006, s. 83). İnsanın doğası gereği açgözlü olmasından kaynaklanan tehlikeler nedeniyle çıkarcı olduğunu savunan Hobbes'a (2007b, s. 27) göre, "Her insan kendisi için iyi olanı arzulamak ve kötü olandan, en başta da doğal kötülüklerin en büyügü olan ölümden, kaçınmak zorunda kalır; bu, taşın yere düşmesi kadar güçlü ve doğal bir zorunluluktur”. Hobbes'un antropolojik doğal durum tasarımı üzerine görüşleri, herkesin herkese karşı savaşına odaklanarak herkesin iyiliği adına bir iktidar tekeliyle kaosa son vermeyi vaat eder (Kaufmann, 2003, s. 43). Bu boyutuyla Hobbes'un, doğal durum modeli, devletin varlığını haklı çıkarmaya yönelik argümanlar içerir. Bu anlamda Leviathan, saf pragmatik sebeplerle var olur ve devletin varlığı aklanır (Newman, 2006, s. 87). Hobbes, düşünebilme kapasiteleri olan insanların gelecek korkusu içinde yaşadıklarını dolayısıyla gelecekte ellerindekilerin tükeneceği korkusunun onları hayvanlardan daha tehlikeli yaptığını belirtir.

$\mathrm{Bu}$ gerekçelerle insanların korku tekelini elinde bulunduran güçlü bir otorite tarafindan kontrol edilmesi gerektiğini ileri süren Hobbes'a (2007a, s. 127) göre, "Kılıcın zoru olmadıkça ahitler sözlerden ibarettir ve insanı güvence altına almaya yetmez". Bu nedenlerle kendi başlarına oldukça tehlikeli işler yapabilme potansiyeli taşıyan insanların dizginlenmesi için güçlü bir otoritenin var olması gerektiği vurgulanır.

\subsubsection{Toplumsal Sözleșme}

Hobbes (2007b, s. 11) insanların birbirlerinden korkmasını toplumsal sözleşmeyle bir arada yaşamalarının gerekçesi olarak değerlendirir. Hobbes’a göre, “insanlar doğal karakterleri gereği genel bir gücün korkusu tarafından sınırlandırılmadıkça birbirlerine güvenmezler ve birbirlerinden korkarlar, bundan dolayı da herkes hakkaniyetli bir şekilde ve zorunlu olarak kendi kaynaklarına dayanarak kendi başının çaresine bakar”. Bu bağlamda Hobbes, sosyalleşmenin nedenlerini sevgiden ziyade karşılıklı korkuya dayanan bir çeşit politik ilişskinin gelişmesiyle açıklar ve bunun asla iyi niyete dayalı olmadığını belirtir. Hobbes (2007b, s. 24), "Bu nedenle büyük ve köklü toplumların kökenine karşılıklı sevgi değil ama insanların birbirine karşı duydukları korkunun konması gerekir”, görüşünü savunur. Bu anlamda Hobbes, insanların doğal olarak sosyalleşebilir nitelikte olmadıklarını savunur ve insanların sosyalleşmelerini karşılıklı korku ve güvensizliğe indirgeyerek insan doğasına yönelik karamsar bir yaklaşım sergiler.

Hobbes (2007a, s. 92), toplumsal sözleşme öncesi, doğal halin varoluşunu Doğa'nın insanları doğuştan eşit yaratmasıyla açıklar: "Bazen bir başkasına göre bedence çok daha güçlü veya daha çabuk düşünebilen birisi bulunsa bile, her şey göz önüne alındığında, iki insan arasındaki fark, bunlardan birinin diğerinde bulunmayan bir üstünlüğe sahip olduğunu iddia etmesine yetecek kadar fazla değildir”. Bu anlamda Hobbes, doğanın insanları eşit olarak yarattığını savunur ve söz konusu eşitliğin olumsuz yönlerini vurgular. "Hobbes, doğuştan 
sahip oldukları güç yetileri bakımından olduğu gibi, güç mücadelesi bakımından da insanların eşit olduklarına işaret eder; çünkü insanların eşitliği, her birinin doğaları gereği birbirlerini öldürebilecek yeterli güce sahip oldukları gerçeğine dayanmaktadır" (Arendt, 2014, s. 38). Bu durum doğal haldeki, herkesin herkese karşı savaş halinde olmasının en temel noktasıdır. Bu temelde Hobbes, eşitliğin güvensizliğe, güvensizliğin ise savaşa yol açtığını savunur. Hobbes’a (2007a, s. 93) göre, "Bir şeyin eşit pay edildiğinin en büyük kanıtı, herkesin kendi payından memnun olmasıdır". Bu anlamda doğa durumundaki eşitlik, güvensizliğin ve herkesin herkese karşı savaş halinde olmasının önemli bir faktörüdür. Hobbes'a göre, insanların doğal olarak eşit olduğu durumda, "Zayıflık, kurnazlıkla telafi edilebilir. İnsanların potansiyel katiller olmaları bakımından eşitlikleri, bütün insanları aynı güvensizlik durumuna sokar; bir devlet ihtiyacı buradan doğar. Devletin varoluş nedeni, kendini hemcinslerinin tehdidi altında hisseden bireyin güvenlik ihtiyacına dayanır" (Arendt, 2014, s. 38). Bu doğrultuda eşitlikten kaynaklanan güvensizlik, korku ve savaş durumu toplumsal sözleşmeyi rasyonel bir zorunluluk olarak ortaya çıkarır. Bu çerçevede çizilen "karamsar gerçeklik", doğal haldeki eşitliğin kaosa yol açması ve kaostan çıkış için iktidarın mutlak bir otoriteye devredilmesi gerektiği sonucu çıkarılır. Bu ise toplumsal sözleşmenin mantığını oluşturmaktadır.

Hobbes tarzı toplumsal sözleşme teorilerinde, insan doğasının istisnai sayılabilecek nitelikteki olumsuz tasvirleri temel alınır. Bahsi geçen teorilerde, insanların doğaları gereği, bencil, agresif, rekabetçi olduklarına dair tezler bulunur. Bu doğrultuda insanların doğal halde bireysel dürtüleri gereği çatışma içine girecekleri dolayısıyla "herkesin herkese karşı”" savaşına dahil olacakları iddia edilir (Newman, 2006, s. 83). Bu anlamda Hobbes'un soyutlamalara dayalı insan doğası tasvirleri, insanlara birey olarak güvenmenin yanlışlığını ortaya koyar ve insanlar arası dayanışmanın spontane biçimde gelişemeyeceğini öngörür. Bu öncüllerden yola çıkılarak insanın istikrarlı ve güvenli bir yaşam sürmesi, devletin varoluşuna bağlanır.

\section{Yöntem}

Felsefe-film ilişkisine yönelik iki farklı yaklaşım bulunmaktadır. Bir tarafta filmlerde ele alınan felsefi konuların incelenmesi amaçlanmakta, diğer tarafta bir sanat biçimi olarak filmin ortaya çıkardığı konular üzerinde durulmaktadır. İlk yaklaşımda filmlerin çeşitli felsefi meselelere getirdiği bakış açıları sorgulanırken ikinci yaklaşımda teknik olanaklar bağlamında sinematik imkanların yarattığı etkilerin felsefi önemi üzerinde durulmaktadır (Cox ve Levine, 2012, s. 3). Filmlerde ele alınarak sinematik tarzda somutlaştırılan adalet, etik, estetik, yaşamın ve ölümün anlamı gibi konular birinci yaklaşımın felsefi bağlamda ilgilendiği konuları oluşturmaktadır. Sinematik imkanlar felsefi sorun ve argümanların derinleştirilmesine, somutlaştırılmasına ve farklı perspektiflerden ele alınmasına olanak sunmaktadır. Bilindiği üzere filozofların ileri sürdüğü kimi düşüncelerin tartışılması açısından filmler, felsefi meseleleri ele almanın ve yazılı felsefede ileri sürülen önerme, aksiyom ve savları somutlaştırmanın önemli bir yoludur (Öztürk, 2018, s. 34). Bu anlamda insan doğasına dair karamsar düşünceleri içeren "İnsan insanın kurdudur" sözünün tartışılması bu çalışmanın temel amacını oluşturmaktadır. Bu bağlamda İspanyol yönetmen Galder Gaztelu - Urrutia imzalı The Platform (2019), insan ve yaşam üzerine ileri sürülen düşünceler hesaba katıldığında felsefi tonu belirgin bir film olarak dikkat çekmektedir. The Platform, insana dair felsefi bir düşüncenin ifadesi olan "insan insanın kurdudur" sözünü sinematik olanaklarla somutlaştırmakta ve yazılı felsefede ele alınan bir düşüncenin sinematik imajlarla tartışılmasına olanak sunmaktadır. Bu doğrultuda çalışmada önce Thomas Hobbes'un geliştirdiği insan paradigması, "insan insanın kurdudur" sözü, "doğa durumu” ve "toplumsal sözleşme” kavramları çerçevesinde açılanmakta ardından The Platform, söz konusu kavramlar bağlamında çözümlenmektedir.

\section{The Platform Filminin Analizi}

\subsection{Filmin Konusu}

The Platform'da, yöneticiler tarafından Dikey Öz Yönetim Merkezi, içerdekiler tarafından delik" olarak isimlendirilen gizemli bir yapı içinde belli bir süre kalmak zorunda olan kimi insanların hayatta kalma mücadeleleri anlatılır. Yapı içinde her hücrede iki kişi otuz günlük sürelerle kalır ve bir ay sonra bulundukları katlar rastgele değiştirilir. Yapının en üst katındaki mutfakta, özenli biçimde yiyecekler hazırlanır ve yukarıdan aşağıya doğru her katta belli bir süre kalacak şekilde gönderilir. Menü yapı içinde bulunan insanların her birinin en çok sevdikleri yemekleri içerir. Büyük özenle hazırlanan yemekler hiçbir yere bağlı olmayan bir platform üzerine yerleştirilerek yukarıdan aşağıya doğru gönderilir. Platform her katta belirli bir süre kalır ve içerdekilere yemekler sunulur. Yapının içinde üst katlardan alta doğru inildikçe yemek için mücadele artar ve alttakiler üsttekilerin artıklarıyla beslenmek zorunda kalırlar. Yapının içinde alt kattakiler sadece yukarıdakilerin bıraktıklarını yiyebilirler ve platform bir sonraki kata inince, herhangi biri yiyeceklerden bir parçayı elinde tutmaya çalışırsa hücre ölümcül derecede ya 1sıtılır ya da soğutulur. En alt katlara doğru inildikçe platformun üzerinde yemek kalmaz. Yemeğin ulaşmadığı katlarda hayatta kalmak oldukça zorlaşır.

Dikey Öz Yönetim Merkezi ya da "delik" kimi açılardan suçluların kapatıldığı bir hapishane gibidir, içinde çeşitli suçlardan yatanlar bulunur. Diğer taraftan çeşitli nedenlerle gönüllü olarak bir süreliğine içeri girenler de vardır. Bu yapının bir özelliği de bir çeşit eğitim merkezi olmasıdır nitekim deliğe girip sağ çıkanlara bir 
diploma verilmektedir. Goreng (Ivan Massagué), sigarayı bırakmak için kendi isteği ile Dikey Öz Yönetim Merkezi'ne katılmak için başvurur fakat sistemin nasıl çalıştığı ve içerde tam olarak nelerin olup bittiğinden habersizdir. Dikey Öz Yönetim Merkezi’nde uygulanan sisteme göre, herkes içeri girmeden önce yanlarına alacakları bir nesneyi seçmek ve menüye dahil edilmesi için en çok sevdikleri yemeğin ismini vermek zorundadır. Goreng, yanına alacağı nesneyi kitap olarak belirler ve Cervantes'in Don Quijote adlı romanını seçer. Goreng’in yapı içindeki serüveni seçtiği romanın kahramanıyla benzeşerek donkişotvari bir serüvene dönüșür.

\subsection{Kurtlar Sofrası Olarak Platform}

The Platform, Hobbes'un doğa durumu kurgusuyla benzer biçimde insan doğasına yönelik kötümser bir yaklaşımla örülüdür. Filmde aç kalma korkusuyla ihtiyaçlarından daha fazlasını tüketen ve dayanışma yerine birbirleriyle vahşi bir rekabet içine giren insan portreleri çizilir. Filmin açılışındaki mutfak sahnesinden hemen sonra söylenen "Üç tür insan vardır: Yukarıdakiler, aşağıdakiler ve düşenler", biçimindeki sözler, insanlar arasında yaşanan hiyerarşik ilişkileri açıklar. Bahsi geçen sözler filmin temel iletisini içerir.

Herkesin 30 günlük sürelerle tutulduğu katlardan alt katlara inildikçe yemek sıkıntısı nedeniyle intiharlar ya da birbirini öldürüp yeme gibi eylemler çoğalır. Yapı içinde herkese yetecek kadar yemek yapılır dahası herkesin en çok sevdiği yemekler menüye dâhil edilir. Bu duruma rağmen üsttekiler yedikleri yemekleri yağmalayıp kirletirler. Üstten alta doğru inen platformun üzerindeki yemekler, insanların aç gözlülügü nedeniyle aşağ 1 inildikçe tükenir. Dayanışma ve paylaşma yerine rekabeti seçen yapı içindekiler birçok insanın aç kalmasına ve ölmesine yol açar. Üsttekiler alttakileri düşünmez, duygudaşlık yapmazlar. Yapı içindeki insanlar paylaşılırsa herkese yetecek kadar yemeğin olduğunu bilmelerine ve 30 gün sonra kendilerinin de alt katlara düşme ihtimalleri olduğunun bilincinde olmalarına rağmen dayanışma ve paylaşma yerine ölümcül bir rekabet içine girerler. Bu durum insanların kötücül doğalarına açık biçimde gönderme yapar. Filmde insanlar arası ilişkilere, açlık korkusu, aç gözlülük ve spontane dayanışma yerine rekabetin egemen olması Hobbes'un doğa durumu'unda tasvir ettiği insan modelini çağrıştırır. Yemeklerin dağıtımı için işlev gören platform, insanların birbirlerine karşı kurtlaşmalarının sembolüne dönüşür.

\section{3. İki Farklı İnsan İmajı: Goreng ve Trimagasi}

The Platform'da insan doğasına yönelik oldukça kötümser bir yaklaşım sergilenir. "İnsan insanın kurdudur” sözü filmde birçok karakter üzerinden farklı gerekçelerle somutlaştırılır. Kötücül karakterlerin egemen olduğu filmde iki farklı insan imajı çatışır. İstisnai bir portre çizen başkarakter Goreng, gözlerini açtığında duvardaki 48 rakamından bulunduğu kat anlaşılır. Aynı kat içinde Trimagasi (Zorion Eguileor), isimli yaşlı bir erkek de vardır. Film boyunca Trimagasi ve Goreng arasında yaşananlar iki farklı insan anlayışı ortaya koyar. Bir tarafta yanına kitap alarak içeri giren Goreng diğer tarafta kendini bileyen bir bıçakla içeri giren Trimagasi bulunur. Trimagasi kötümser, rasyonel ve gerçekçi bir portre çizerken Goreng, realite karşısında ideali savunan bir romantik olarak tasvir edilir. Kitapların dünyasından gerçek dünyanın içine girmek Goreng'in teorisinin pratikle sınanmasına yol açar. İkilinin diyaloglarından Goreng'in sigarayı bırakmak için tesise gönüllü olarak katıldığı ve altı aylık sürecin sonunda bir diploma alarak çıkacağı anlaşılır. Trimagasi ise bir göçmenin ölümüne yol açması nedeniyle bir yıllık hapis cezası çekmektedir. Trimagasi akıl hastanesine girme alternatifini reddederek cezasını "delik"te geçirmeyi seçmiştir. Trimagasi pragmatist bir kişilik olarak her olaya kâr zarar hesabı üzerinden yaklaşır. Goreng'in altı aylık süreç sonunda bir diploma alacağını öğrenmesi ancak kendisine diploma vaat edilmemesine verdiği tepki Trimagasi'nin pragmatist kişiliğini somutlaştırır. Trimagasi her konuda olduğu gibi diyalog kurmayı da çıkar hesabıyla yapar, alacağı bilgi karşısında bilgi verir.

Trimagasi'nin kötümser gerçekçiliği hayatta kalmak adına her türlü yola başvurmasının dayanağını oluşturur. Trimagasi'nin, yemeğin ulaşmadığ1 132. katta yukardan platformun üstüne düşerek ölen bir kişinin etiyle beslendiği anlaşılır. Goreng delikte yaşananlar karşısında dehşete düşmeye başlar ve yukarıdakilere seslenerek yiyeceklerin eşit biçimde tüketilmesi çağrısında bulunur. Trimagasi, Goreng'in anlamsız bir çaba içine girdiğini düşünür ve yukarıdakilerin komünistleri dinlemeyeceklerini belirtir. Goreng bölüşmenin adil olacağını bunun aklın gereği olduğunu söylese de Trimagasi'yi ikna edemez. Trimagasi, Goreng’i yukarda olsa aşağı atlayacak, aşağıda kalmaya ise yüreği yetmeyecek bir tip olarak niteler. Platform üzerinde Miharu (Alexandra Masangkay) adında, yara bere içindeki kadını gören Goreng, ona yardım etmeye çalışır. Trimagasi, Goreng'in kadınla ilgilenmesini kendi pragmatist perspektifinden yorumlar. Trimagasi’ye göre, Goreng, cinsel çıkar sağlamak amaciyla kadınla ilgilenmektedir.

Goreng ve Trimagasi yaşama ve insanlara farklı perspektiflerden bakarlar ancak birlikte zaman geçirmeleri onları yakınlaştırır. Birlikte geçirdikleri ilk ay arkadaş olurlar ancak ikinci ay 48. kattan 171. kata atılmaları durumu değiştirir. Açlık tehlikesini öngören Trimagasi, Goreng'i uykudayken yatağa bağlar ve yiyecek bulamaması durumunda hücre arkadaşının etiyle beslenmeyi planlar. Durumu dehşetle fark eden Goreng, ona yalvarır. Bir ay su içerek hayatta kalabileceklerini söyler ancak risk almak istemeyen Trimagasi Goreng’i parça parça kesip yiyeceğini, bir taraftan da onu tedavi edeceğini söyler. Platformdan yemek gelmemesi üzerine 
Trimagasi, Goreng'in vücudunu kesmeye girişir. Tam o esnada platformun üzerinde aşağı inen Miharu, Trimagasi’ye saldırır ve onu yaralar. Miharu, Goreng'i serbest bırakır ve bıçağı ona verir. Goreng, çektiği acının öfkesiyle Trimagasi'ye saldırır ve onu öldürür. Miharu, Trimagasi'nin etinden parçalar keserek yer ve Goreng’i de besler. Goreng ilk başta Trimagasi'nin etini yemek istemez ancak açlığ 1 artıkça onun kurtlanmış cesedinden bir şeyler koparıp yiyerek hayatta kalır. Bu süreçte Goreng halüsinasyonlar görmeye başlar ve öldürdüğü Trimagasi'yle tartışır. Goreng, hayatta kalmak için gittikçe Trimagasi’ye benzediğini fark eder ancak kişiliğinden ve düşüncelerinden taviz vermemek için direnir. Goreng ve Trimagasi ile kurgulanan insan imajları insanların ölüm korkusu karşısında canavarlaşabileceklerini ve birbirlerinin kurdu olma durumlarının kaçınılmaz olduğunu vurgular. Bu doğrultuda Hobbes'un doğa durumunda tasvir ettiği insan imajı filmde somutlaştırılır ve insanlar hayatta kalmak adına sürekli birbirleriyle savaş durumunda yaşarlar.

\subsection{Spontane Değişimin İmkansızlığı}

Goreng, üçüncü ayda yiyecek bulmak açısından daha rahat olan 33. katta uyandığında, yeni hücre arkadaşı Imoguiri (Antonia San Juan) ve II. Ramses adlı köpeğiyle karşılaşır. Kadın önceden Goreng'i tanımaktadır bu nedenle Dikey Öz Yönetim Merkezi'nin eski bir çalışanı olarak onunla aynı hücreyi paylaşmayı seçmiştir. Goreng, Imaguiri'den kendisini delikten çıkarmasını ister ancak kadın bunun imkânsız olduğunu belirtir. Goreng, Imaguiri’yle “delik” hakkında tartışır. Miharu'nun çocuğu hakkında sorular sorar. Imoguiri 16 yaşından küçük çocukların tesise girmesine izin verilmediğini ve Miharu'nun tek başına girdiğini söyler. Imoguiri yapı içindeki korkunç işleyişin pek de farkında değildir. Üç yıl boyunca mücadele ettiği hastalığa yenildiğini kabul ettikten sonra merkeze gönüllü olarak girmiştir. Imoguiri, diğer insanları düşünerek yemeğini köpeğiyle paylaşır ayrıca her gün iki kişilik porsiyonlar hazırlar ve alt kattakilerin de kendisi gibi davranarak yemekleri eşit paylaşmalarını ister ancak alttakiler onu dinlemezler. Imoguiri insanların spontane biçimde dayanışmayı öğrenmeleri gerektiğini savunur ve ısrarla alt kattakilere düşüncelerini açıklar. Goreng ise yaşadığı deneyimler nedeniyle dayanışmanın ve değişimin kendiliğinden ve güzellikle olmayacağına kani olmuştur. Ona göre değişim asla spontane biçimde gerçekleşmez.

Imoguiri 1srarla her gün yemek ayırır ve alttakilere tebliğde bulunur ancak sürekli hakaretlerle karşılaşır. Bir süre sonra Goreng alt kattakilerin duyarsızlığı karşısında öfkesini kontrol edemez ve onlara eğer kadını dinlemezlerse yemeklerin üzerine işeyeceği tehdidinde bulunur. Goreng'in tehdidi etkili olur. Sözle ve akla dayalı argümanlarla ikna olmayan insanlar korkudan etkilenirler. Bu durum Hobbes'un insanların yaşamında korkunun belirleyiciliğine yaptığ 1 vurguyla uyumlu görünür. Belirtildiği üzere Hobbes insanların doğa durumunda birbirlerinden korktukları için sürekli savaş durumunda olduklarını savunur diğer taraftan devletin varoluş gerekçesini korkuyla temellendirerek üst bir otoritenin varlığının gerekliliğini vurgular. Belirtildiği üzere Hobbes, doğa durumunda toplumsal sayılabilecek hiçbir şeyin olmadığını ileri sürer ve insanı doğası gereği sosyalize olmaya yatkın bir varlık olarak görmez. Bu bakış açısı filmde somutlaştırılır. İçerdeki insanlar diğer insanlarla birlikte hareket etmek istemezler ve birbirlerine karşı acımasız bir rekabetin içine girerler.

Bir süre sonra Goreng, insanları korkutmanın akılcı dayanışma önerilerinden ve ikna çabalarında daha etkili olduğunu kabul etmeye başlar. Alt kattakileri ikna edemediği için üzülen Imoguiri bu sefer de üst kattakileri ikna etme ihtimali üzerine düşüncelerini açıklar. Goreng ise yaşadığı deneyimlerden yola çıkarak üst kattakilerin kendilerini dinlemeyeceğini kesin biçimde belirtir. Bir süre sonra, Miharu'yu yaralı biçimde platform üzerinde gören Goreng Imaguiri'den yardım ister ve onu hücreye taşırlar ancak Miharu II. Ramses'i öldürür ve yer. Köpeğinin öldürüldüğünü gören Imoguiri yıkılır, yemek yemeyi bırakır ve tamamen yaşama küser. Miharu, yap1 içinde sürekli ölme ve öldürme ikilemi içinde çocuğunu arayan bir kadın olarak hayatta kalabilmek için kurtlaşmıştır. Miharu, canavarlarla mücadelesinde canavarlaşmaktan başka bir yol göremediği için karşısına çıkan engelleri şiddetle aşmayı öğrenmiş ve sürekli biçimde savaş durumunda kalmaya zorlanmıştır. Dikey Öz Yönetim Merkezi içinde istisnai bir insan olan Goreng dışında kimse Miharu'nun çocuğunu aramasını dert edinmez. Miharu birçok kez tecavüze uğrama ve öldürülme riskiyle yüz yüze kalır. The Platform'da Miharu'nun yaşadıkları üzerinden insanların acımasız oluşları ve başka insanların acılarına duyarsız kalışları etkili biçimde tasvir edilir. Goreng çizdiği istisnai insan imajlıya bir çeşit "Mesih" olarak nitelenir.

\subsection{Sisteme Karşı Don Kişotvari İsyan}

Goreng sonraki ay 202. katta uyanır ve Imoguiri’yi hücrede intihar etmiş halde bulur. Goreng hayatta kalmak için bu sefer de İmaguri'nin etini yemek durumunda kalır. Açlık, intiharlar ve ölümler karşısında dehşeti yaşayan Goreng sürekli halüsinasyonlar görmeye başlar. Hobbes'un doğa durumunda "insan yaşamı yalnız, yoksul, kötü, vahşi ve kısa sürer”, biçimindeki saptamaları Dikey Öz Yönetim Merkezi’nde yaşananlarla somutlaşır. Trimagasi ve Imoguiri düşlerinde Goreng'i sürekli rahatsız ederler. Goreng çıldırmanın eşiğine gelir. Açlıktan kitabın sayfalarını yemeye başlar. Bu durum aç kalan insanların düşüncelerini yemeye başladıkları yönündeki özdeyişi çağrıştırır. Sürekli düşle gerçek arasında gidip gelen Goreng, Imaguiri'nin etini yemekle yememek arasında ikilem yaşar. Goreng'in “insan” kalmakla canavarlaşmak arasında yaşadığı ikilem bireysel düzlemde çetin bir mücadeleye sahne olur. 
Goreng halüsinasyonlarla, açlıkla ve kabuslarla geçen dördüncü aydan sonra 6. katta uyanır. Yeni hücre arkadaş1 Baharat (Emilio Buale) isimli, fiziksel açıdan oldukça güçlü siyahi bir erkektir. Baharat elinde urganıyla üst katlara çıkmaya çalışır. İnançlı bir insan olan Baharat elindeki urganla 5. kattakilere seslenir ve yukarı çıkmak için yardım ister. Üst katta bir erkek ve kadın bulunur ve yardım edeceklerini söyleyip ipi atmasını isterler. Baharat ipi atar ve ipe tutunarak tırmanmaya başlar. Yukarıdakiler Baharat'ın elinden tutmadıkları gibi kadın onun üzerine dışkısını yapar ve düşmesine yol açar. Goreng'in yardım etmesiyle Baharat boşluğa düşüp ölmekten kurtulur. Baharat büyük hayal kırıklığı yaşar ve bir daha çıkış şansı yakalayamayacağını düşünür.

The Platform'da içeri girenlerin yanlarına almak için seçtikleri nesneler yaşama bakışlarını yansıtır. Goreng'in yanına aldığı nesne Cervantes'in Don Quijote adlı kitabıdır. Kitabın kahramanı Don Kişot dünya edebiyatının önemli arketipleri arasında yer almaktadır. Don Kişot'un kurgusal kişiliğinden esinle oluşturulan "Don Kişot'luk yapmak", sözü çoğu zaman sonuç vermeyecek çabaların içine girenlerin durumunu açıklamak için kullanılmaktadır. Belge'nin (2009, s. 360) tanımladığı biçimiyle “Don Kişot'luk”, yanlış olduğunu düşündüğün bir olay karşısında, kendi başarı şansının ne olduğuna dair hesap yapmadan, müdahalenin sana verebileceği zararları düşünmeden, eyleme geçmek ve gördüğün bu haksızlığı önlemek üzere davranmaktır”. Bu anlamda "Don Kişot'luk", insani bir tutum ve yaşam karşısında bir tavır alış olarak değerlendirilebilir. Bu çerçevede Goreng, seçtiği kitabın kahramanıyla özdeş bir tutum içine girerek Dikey Öz Yönetim Merkezi’nin uyguladığ sisteme karşı Don Kişotvari bir tutumla isyan eder.

Goreng, altıncı kattaki beslenme ve dinlenme olanaklarını değerlendirmesi halinde yapı içinde iki ay daha kalarak çıkabileceğini öngörür. Goreng bireysel kurtuluş imkânı olmasına rağmen sadece kendini kurtarmayı reddeder ve sisteme karşı isyan eder. Değişimin kendiliğinden olmayacağına kani olan ve yukarı kattakilerden umudunu kesen Goreng, değişim için aşağı katlara inilmesi gerektiğine karar verir. Tek başına başarılı olmasının imkânsız olduğunu bilen Goreng, Baharat'tan yardım ister. Baharat isyan girişimini intihar etmekle özdeş görür ancak Goreng'in söyledikleriyle ikna olur ve değişim için mücadele etmeyi kabul eder. Goreng ve Baharat platformu kontrol edip herkese eşit miktarda yemek dağıtarak en aşağı kata kadar inmeye karar verirler. Böylece yapının mekanizmasını işlevsiz hale getireceklerdir. Goreng ve Baharat aşağı katlara inmenin kolay olmadığının bilinciyle ranzalardaki demir çubuklardan kendilerine silah yaparlar. Goreng ve Baharat, yemek dağıtımını 51. kattan başlatmak isterler ancak yemek yemelerine izin verilmeyenler iş birliği yapmayı redderler.

İsyancılar, taviz vermeden en alta inebilmek için şiddete başvururlar ve canavarlığa karşı mücadelelerinde acımasızlaşırlar. Alt katlardan birinde Baharat'ın tanıdığı bilge adam ikilinin mücadele yöntemini eleştirir. Onlara şiddet kullanmadan önce ikna yöntemine başvurmaları gerektiğini söyler. Bilge adam, Goreng ve Baharat'ı vicdanı olmayan yönetim yerine küçük bir ihtimal de olsa vicdan sahibi olabilecek sıfırıncı katta bulunan mutfaktakilere bir sembolle mesaj iletmelerini önerir. Bu mesaj ise "Panna cotta" isimli leziz bir yemek olarak belirlenir ve onun el sürülmeden sıfırıncı kata geri gönderilmesi hedef olarak belirlenir. Böylece yukarıya bir mesaj gönderilecektir. Bilge adamın önerileri doğrultusunda alt kattakiler bir gün oruç tutmaya çağrılırlar ancak ikna çabaları sonuç vermeyince dayanışmayı reddedenlere karşı şiddet kararlı biçimde tekrar uygulanır.

Alt katlara inildikçe mücadele fiziksel ve psikolojik olarak ağırlaşır. Alt katlardan birinde iki erkek Miharu'ya saldırırken görülür. Goreng ve Baharat, Miharu'ya yardım etmeye çalışırlar ancak kadın öldürülür ve onlar da ağır biçimde yaralanırlar. Goreng ve Baharat yaralı halde alt katlara inmeye devam ederler. Platform 333. katta durur, Goreng, muhtemelen Miharu'nun kızı olan bir çocuğun yatağın altında saklandığını fark eder. Goreng platformdan iner, tereddüt içindeki Baharat da onu izler. Bu esnada platform aşağı iner ancak 333. katta yiyecek bulunmasına rağmen bir 1sı değişimi yaşanmaz. Goreng, Baharat'tan “panna cota”nın bir kısmını oldukça aç olan çocuğa vermesini ister. Baharat tereddüt yaşar ancak büyük özen ve fedakarlıkla koruduğu ve umut bağladığ yiyeceği kıza verir. Ağır yaralı olan Goreng ve Baharat kendilerinden geçerler. Goreng, yine halüsinasyonlar görmeye başlar ve Baharat'ın kızın mesaj olduğunu söylediğini sanır. Sonraki planda Goreng, uyanır ve Baharat'ın öldüğünü fark eder. Çocuğu yanına alan Goreng, platformun üzerine çıkar ve mesajı yukarı iletmek için bekler. Platformun üzerinde Goreng tekrar halüsinasyonlar görmeye başlar ve Trimagasi'yle konuşur. Trimagasi ona yolun sonuna geldiğini söyler ancak Goreng, mesaj1 iletmesi gerektiğini söyleyerek onun söylediklerini reddeder. Trimagasi Goreng'e mesajın kız çocuğu olduğunu ve taşıyıcıya ihtiyacı olmadığııı söyler. Bu sefer Trimagasi'nin söylediklerini doğru bulan Goreng, platformdan iner ve onunla konuşmaya başlar. Goreng ve Trimagasi mesajın verilmesinin başarılıp başarılamayacağı hakkında konuşurlar. Goreng'in platformdan inmesi ve Trimagasi’yle birlikte gitmesi öldüğünü imler. Küçük kız 1şık huzmesi altında görünür ardından platformun üzerinde hızlı biçimde yukarı doğru yükselir. Mesajın iletilip iletilmediği belirsiz bırakılır ve film açık uçlu biçimde son bulur.

\section{Sonuç}

Thomas Hobbes, mutlak gücü ve korku tekelini elinde toplayan güçlü bir otoritenin varlığını rasyonel gerekçelerle haklı ve gerekli göstermek için insanı doğa durumu koşullarında tasvir ederek bir insan anlayışı ortaya koymuştur. Hobbes'un politik amaçlar doğrultusunda soyutlamalara başvurarak çizdiği doğa durumu 
içindeki insan modeli, insanların yapıları gereği çıkarcı, rekabetçi ve açgözlü olduğu yönündedir. Bu çerçevede Hobbes'un tarif ettiği insan modeli oldukça egoist, çatışmacı ve savaşçı karakterdedir. Hobbes'in vurguladığ üzere insanlar yaşamlarında birçok şeye gereksinim duyarlar. Bu gereksinimlerin karşılanması en başta hayatta kalmaya ve yaşamı sürdürmek için güvenli bir ortamın sağlanmasına bağlıdır. Bu eksende insanların hayatta kalma endişeleri ve ölüm korkusunu temel alan Hobbes, insanlar arası ilişkileri "herkesin herkesle savaşı" biçiminde formülleştirerek mutlak bir otoritenin olmadığı koşulların çatışma ve kaosa gebe olduğunu vurgular. $\mathrm{Bu}$ doğrultuda insan doğası ve insanlar arası ilişkiler ile hayvanlar alemi arasında benzerlikler kuran Hobbes, insana kısmen olumlu nitelikler yüklese de herkesin herkese karşı bireysel çıkarlar uğruna çatışma içinde olduğu bir güvensizlik ve korku ortamını tasvir eder. Hobbes, tükenmeyen arzular, gelecek kaygısı, ölüm korkusu gibi nedenlerle insanların birbirleriyle çatışmalarını kaçınılmaz bir ihtimal olarak ortaya koyar. Söz konusu çatışma ihtimalini minimalize etmek ve kaotik korku ortamını değiştirmek adına Hobbes insanların doğa durumundan çıkışını bir sözleşmeyle olanaklı görerek mutlak bir otorite olan Leviathanik devletin varoluşunu önerir. Bu anlamda Hobbes, insanların doğasına dayanarak kendiliğinden sosyalleşebileceklerine güvenmez ve tek elde toplanmış korkuya dayalı bir iktidarın varlığını insanların istikrarlı ve güvenli biçimde yaşamalarının teminatı olarak belirler. Bu çerçevede bir toplum ve insan kurgusu inşa eden Hobbes, kaotik korkudan monolitik korkuya geçişle insan toplulukları için daha yaşanılabilir bir ortam önerisinde bulunur.

Thomas Hobbes'un doğa durumunda tasvir ettiği insan modeline benzer biçimde insan imajlarının kurgulandığı The Platform, insan doğası üzerine kötümser bir filmdir. Birçok açıdan Hobbes'un tasvir ettiği insan modeliyle uyumlu karakterlere yer verilen filmde insanlığın kurtuluşu için beslenen umutlar tümüyle reddedilmez ancak ortaya konulan insan imajları insanların değişmesinin imkânsızlığını vurgular. Bu açıdan birbirinin kurdu olarak tasvir edilen ve sürekli birbirleriyle savaşan insanların kurtuluşu ütopik ideallere hapsedilir. Bu bağlamda filmde kötü koşulları değiştirmek adına risk alan ve büyük bedeller gerektiren bir mücadele içine giren Goreng'in çabası somut sonuçlar doğurmaz.

Bir ölçüde toplumdan soyutlanmış insanların, belli kurallar doğrultusunda sınırsız özgürlüğe sahip oldukları bir zeminde birbirlerine karşı kurtlaşan insan imajlarına yer verilen filmde hayatta kalma uğruna birbirlerini acımasızca öldüren karakterlerin mücadelesi insan doğasına yönelik yaklaşımı somutlaştırır. Bu çerçevede filmin iletisi, insanların genellikle kötücül bir doğaya sahip oldukları yönündedir. Filmde istisnai nitelikte olumlu karakterler olan Goreng ve Baharat da içine girdikleri koşullar nedeniyle birçok insanı öldürmekte ve onlar da açlık koşullarında insan eti yiyebilmektedir. Bu açıdan filmde, insanların olağanüstü koşullarda Hobbes’un doğa durumundaki insan modeliyle uyumlu biçimde davranışlar sergiledikleri somut biçimde tasvir edilmektedir. Diğer taraftan insanın değişebileceğine, dolayısıyla yaşamın adil bir paylaşım yönünde dönüştürülebileceğine dair düşünceler romantik kahramanlara özgü hayallere indirgenmektedir. İnsanların doğal olarak kötü oldukları yönündeki görüşler fillmde genellikle rasyonel argümanlar çerçevesinde ileri sürülmektedir. Bu durum insanların doğal yapıları gereği rekabetçi, saldırgan ve kötücül oldukları yönlü savları somutlaştırarak insanlara birbirlerine karşı sınırsız mücadele içine girmek ve birbirlerini sömürmek dışında bir gelecek tahayyüllü sunmamaktadır. Filmde insanlığın geleceğine yönelik umutlar tümüyle yok edilmese de insan doğasına dair düşünceler genellikle olumsuzdur. Bu açıdan insana, insanlar karşısında "kurt" olmak dişında başka seçenek bırakılmamaktadır. Bu doğrultuda filmin ilk sahnelerinden birinde "Üç tür insan vardır. Yukarıdakiler, aşağıdakiler ve düşenler", biçiminde ifade edilen düşünce, filmin sonunda tasdik edilmektedir. Filmde yer verilen bu ileti açı biçimde insanlar arasında rekabetin kaçınılmaz olduğunu göstermekte, egoizmi rasyonalize etmekte ve ötekinin zararına bile olsa kişinin kendi çıkarını koruması gerektiğine yapılan vurguyu somutlaştırmaktadır. 


\section{Kaynakça}

Arendt, H. (2014). Totalitarizmin kaynakları - 2: Emperyalizm (4.Bask1). (B. S. Şener, Çev.). İletişim Yayınevi.

Belge, M. (2009). Sanat ve edebiyat yazıları. İletişim Yayınevi.

Cassirer, E. (1980). Insan üstüne bir deneme. (N. Arat, Çev.). Remzi Yayınevi.

Cox, D., \& Levine, M. P. (2012). Thinking through film doing philosophy, watching movies. Willey Blackwell.

Davies, T. (2010). Hümanizm. (E. Bozkırlı, Çev.). Elips Kitap.

Fromm, E. (2014). Marx’ın insan anlayışı (3.baskı). (K. H. Ökten, Çev.). Say Yayınevi.

Gert, B. (2006). Hobbes's psychology. T. Sorell (Ed.), In The Cambrige companion to Hobbes (pp. 157-174). Cambridge University Press.

Heywood, A. (2004). Political theory an introduction. Palgrave Macmillan.

Hobbes, T. (2007a). Leviathan veya bir din ve Dünya devletinin içeriği, biçimi ve kudreti (6.bask1). (S. Lim, Çev.). Yapı Kredi Yayınları.

Hobbes, T. (2007b). Elementa philosophica DE CIVE - Yurttaşlık felsefesinin temelleri. (D. Zarakolu, Çev.). İstanbul: Belge Yayınevi.

Kaufmann, M. (2003). Aydınlanmış anarşi - Siyaset felsefesine giriş. (Y. Coşar, Çev.). Ayrıntı Yayınevi.

Leboeuf, M. (2014). 32 alıntıda felsefe tarihi. (A. Er, Çev.). NTV Yayınevi.

Neiman, S. (2016). Ahlaki açıklık. yetişkin idealistler için bir kılavuz. (N. Tokdoğan, Çev.). İletişim Yayınevi.

Newman, S. (2006). Bakunin'den Lacan'a anti-otoriteryanizm ve iktidarın altüst oluşu. (K. Kızıltuğ, Çev.). Ayrıntı Yayınevi.

Öztürk, S. (2018). Sinema felsefesine giriş: Film yapımı felsefe. Ütopya Yayınevi.

Pieper, A. (2012). Etiğe giriş (2.Baskı). (V. Atayman \& G. Sezer, Çev.). Ayrıntı Yayınevi.

Svendsen, L. Fr. H. (2017). Korkunun felsefesi (2.Baskı). (M. Erşen, Çev.). Redingot.

Zabcı, F. (2015). Thomas Hobbes: Devlet ya da “ölümlü Tanrı”ya övgü. M. A. Ağaoğulları (Ed.), Sokrates'ten Jakobenlere batı'da siyasal düşünceler (6.baskı) (s. 427-456) içinde. İletişim Yayınevi.

Zarakolu, C. D. (2013). Thomas Hobbes'un siyaset felsefesi. Belge Yayınevi.

Zelyüt, S. (2010). Dört adal - Hobbes - Locke - Berkeley - Hume (2. Baskı). Doğu Batı Yayınevi. 